\title{
A possible tsunami deposit at the Cretaceous-Tertiary boundary in Pernambuco, northeastern Brazil
}

\author{
Gilberto A. Albertão ${ }^{a}$, Paulo P. Martins Jr. ${ }^{b}$ \\ a PETROBRÁS, Av. Elias Agostinho, 665-Ponta da Imbetiba, 27.913-350, Macaé, KJ, Brazil \\ ${ }^{\circ}$ Universidade Federal de Ouro Preto, Depto. de Geologia, Campus do Morro do Cruzeiro, 35.400-000, Ouro Preto, MG, Brazil
}

Accepted 1 April 1995

\begin{abstract}
Interdisciplinary and integrated investigations of a stratigraphic succession spanning the Cretaceous-Tertiary (K-T) boundary in Pernambuco (the Poty Quarry section, near Recife), northeastem Brazil, provides direct evidence for the hypothesis of an extraterrestrial bolide impact event. Discussions on the exact position of the K-T boundary point to an impact event in the earliest Danian. One particular bed at the base of the Maria Farinha Formation shows sedimentary characteristics and exotic (probably impact-derived) material which suggest the action of a tsunami wave. The distribution of iridium concentrations throughout the studied succession records a major peak of iridium (up to 69 times the background levels) at about $15-20 \mathrm{~cm}$ above the main tsunami bed.
\end{abstract}

\section{Introduction}

Alvarez et al. (1980) claimed that the biotic mass extinction which took place around the CretaceousTertiary $(\mathrm{K}-\mathrm{T})$ boundary was triggered by the impact of an asteroid. The evidence includes the anomalous enrichment of rare chemical elements (in particular iridium), right at the $\mathrm{K}-\mathrm{T}$ boundary of sedimentary successions in Italy, Denmark and New Zealand.

More recent research (Smit, 1990; Hildebrand et al., 1991; Alvarez et al., 1992) point to peculiarities present in the boundary bed of different places all over the globe, besides the iridium anomaly: shocked quartz, microspherules, microtektites, soot, and the identification of tsunamites and impact craters, all of them related to the $\mathrm{K}-\mathrm{T}$ boundary.

Preliminary investigation of a stratigraphic succession spanning the $\mathrm{K}-\mathrm{T}$ boundary in Pernambuco (the Poty Quarry section, near Recife, and Ponta do Funil area, near the state boundary between Pernambuco and Paraiba), northeastern Brazil (Fig. 1), provide direct evidence for the hypothesis of an extraterrestrial bolide impact event (Albertão, 1993). This is an occurrence particularly interesting, because it is the only $\mathrm{K}-\mathrm{T}$ boundary reference section presently exposed in southern low-latitude regions, without evidence for a hiatus or reworking. The contact between the Gramame Formation and the Maria Farinha Formation is marked by a bed (bed D) interpreted as a tsunami deposit.

The studied area is part of the PernambucoParaíba Basin, a passive-margin rift basin of which the origin is related to the South Atlantic Ocean opening. The studied sedimentary succession was deposited during Maastrichtian and Danian ages and characterizes a marine regressive megasequence, as defined by Chang et al. (1988). 


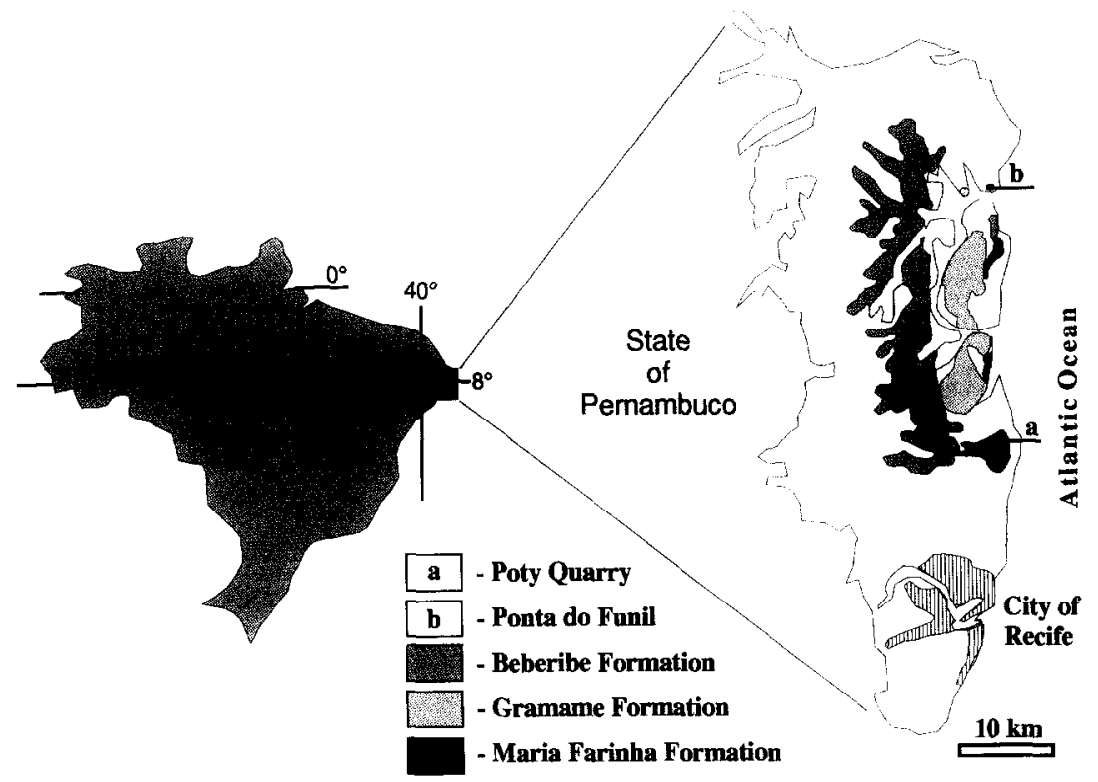

Fig. 1. Location map for the outcrops of Poty Quarry ( $a$, UTM $9152000 \mathrm{~N} / 300000 \mathrm{E}$ ) and Ponta do Funil area ( $b$, UTM $9117000 \mathrm{~N} / 296$ O00E), Pernambuco. The two localities are about $30 \mathrm{~km}$ apart. Starting points for UTM coordinates: $10 \mathrm{Mm} \mathrm{S}$ of the Equator, and $0.5 \mathrm{Mm}$ $\mathrm{W}$ from the meridian $39^{\circ} \mathrm{W}$ of Greenwich, respectively.

Previous detailed stratigraphic studies in the Poty Quarry section have been carried out by Beurlen (1967a, b), Tinoco (1967, 1971, 1976), Mabesoone (1967), Mabesoone et al. (1968), Stinnesbeck (1989), Albertão (1993) and Albertão et al. (1993).

\section{Methods and data analyses}

In general, detailed studies on complete sections including the $\mathrm{K}-\mathrm{T}$ boundary are not available for Brazilian sedimentary basins. However, some outcrop data and drilling results (Albertão, 1993) provided by PETROBRÁS (Petróleo Brasileiro S.A., the State Oil Co. of Brazil) could be used to identify and further study this significant boundary. In this text, some outcrops from the Pernambuco-Paraíba Basin (Olinda Sub-Basin) are described.

Besides field investigations, different samples collected from various outcrops were analyzed using the following methods: (i) petrographic analysis; (ii) micropalaeontological analysis (planktonic foraminifera and palynomorphs); (iii) X-ray diffractometry analysis (XRD); (iv) stable isotope analysis (carbon and oxygen), insoluble residue (IR) and total organic carbon (TOC) analysis; (v) instrumental neutronic activation analysis (INAA), which provided concentrations for 46 chemical elements, including iridium (performed by the Los Alamos National Laboratory team, USA).

\section{Stratigraphy and depositional environment}

Outcrops studied in the Pernambuco-Paraíba Basin, especially those in the Poty Quarry, near Recife, and Ponta do Funil area, near Goiana (both in the State of Pernambuco), show the following sequence (from bottom to top): the Gramame Formation (marly biomicrites of deep neritic-upper bathyal

Fig. 2. Schematic section of the Poty Quarry. Samples 1 to 59 are indicated. Detailed section (lower part, right side of the figure) is shown in Fig. 4. 


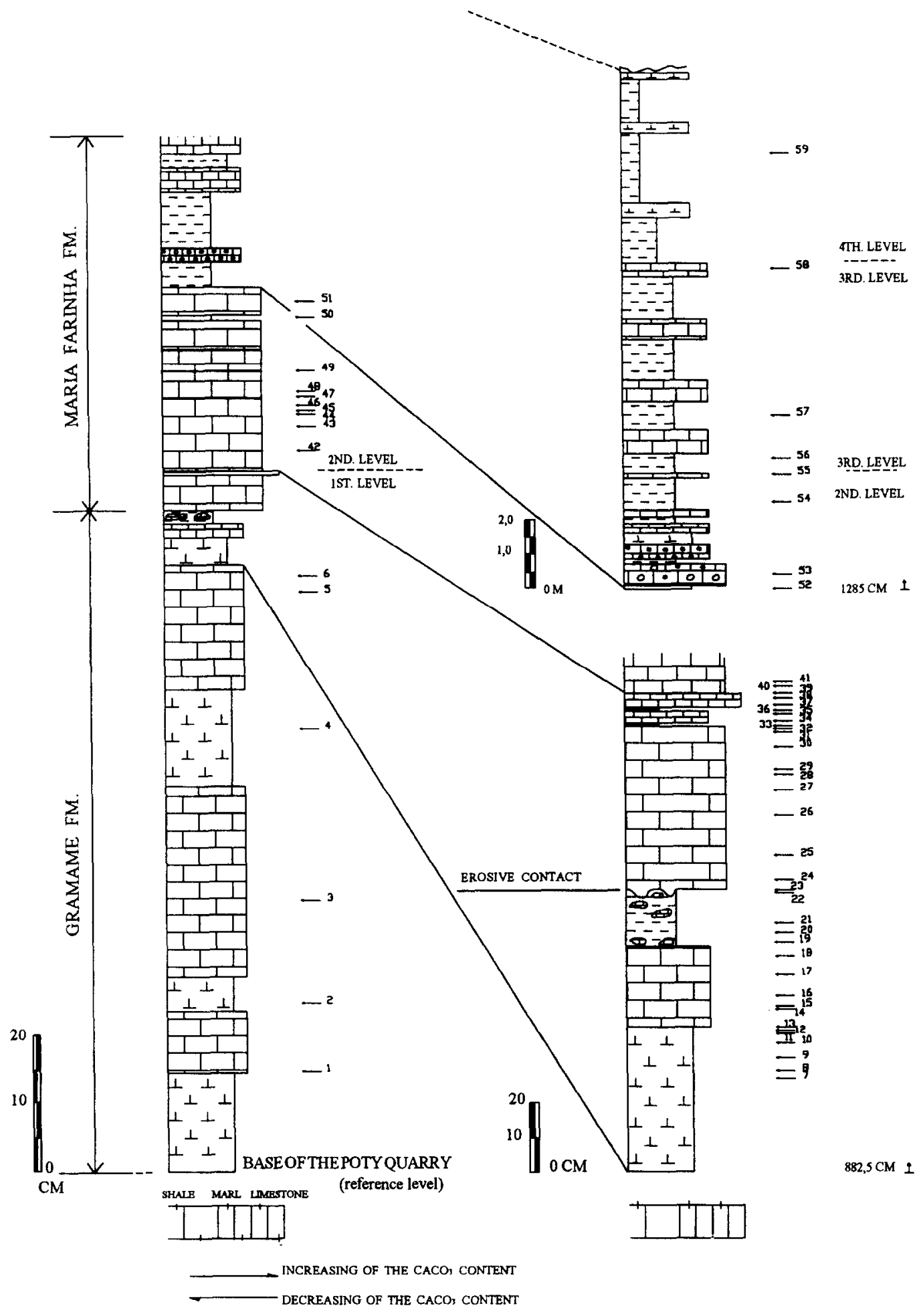


environment) is overlain by the Maria Farinha Formation. The latter consists of alternations between limestones (biomicrites, biosparites and calcilutites) and shales deposited in a middle-deep neritic environment. There is an erosive lithologic contact between these two formations (Fig. 2). The sedimentary structures present at the transition from the
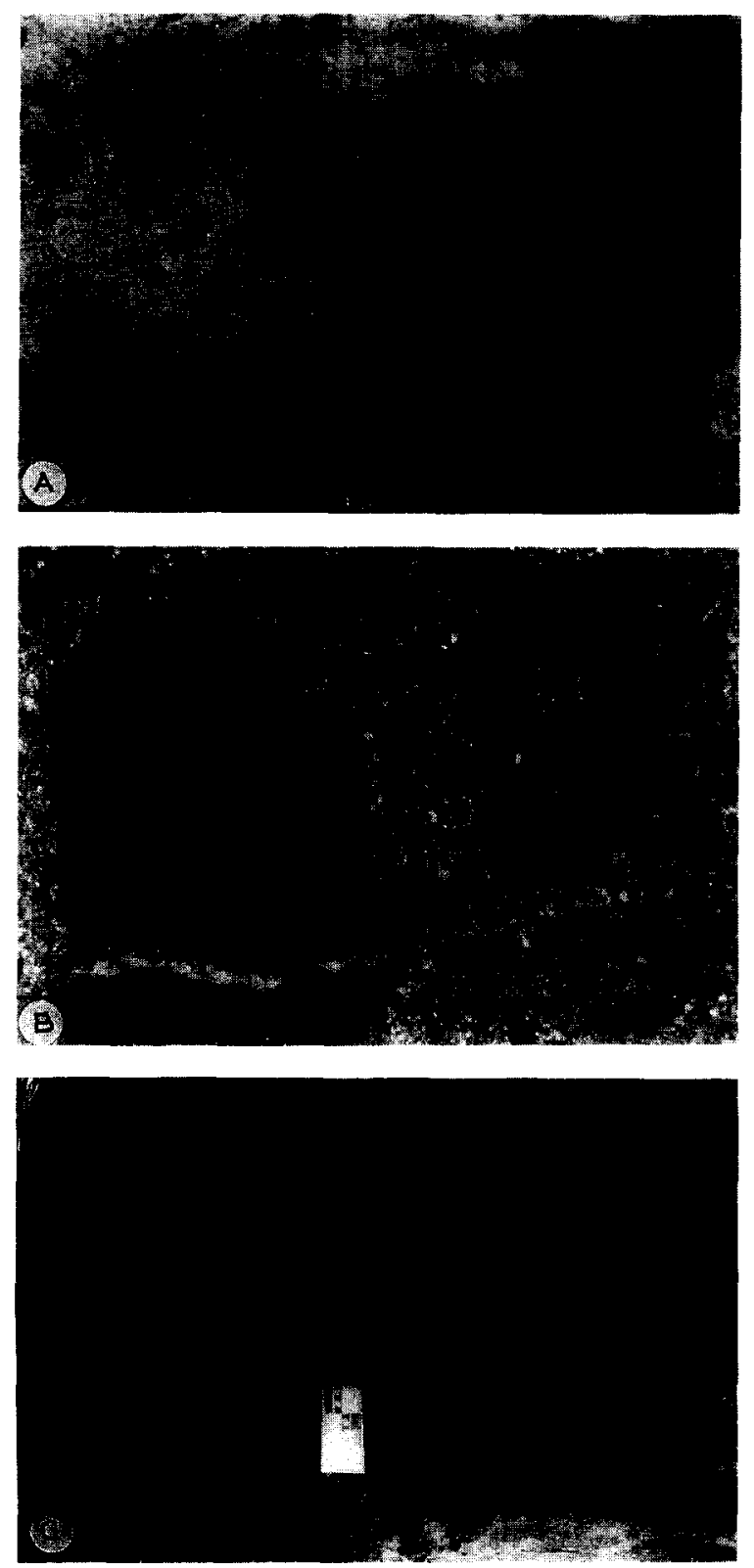

uppermost Gramame Formation to the basal portions of the Maria Farinha Formation (hummocky cross stratification, Fig. 3A, fining-upward and wavy bedding) characterize a carbonate ramp controlled by storms in a process of progressive marine regression (interpretation buttressed up by the ichnofossil, geochemical, palaeontological and mineralogical data; Albertão, 1993).

\section{K-T boundary: peculiarities}

A series of fourteen beds (named $\mathbf{A}$ to $\mathbf{N}$ from the base to the top of the succession) associated to a sequence of geological events was described in detail. The base of the Maria Farinha Formation, particularly bed $\mathbf{D}$ (the first bed of the Maria Farinha succession; Fig. 4), is here interpreted as a sedimentary deposit formed through a process of higher energy than the other beds.

The $\mathrm{K}-\mathrm{T}$ boundary was initially defined (Albertão and Martins, 1992; Albertão, 1993; Albertão et al., $1993)$ as a thin $(2 \mathrm{~cm})$ and continuous marly/shaly bed which is found only in the Poty Quarry (bed I; Fig. 4). The boundary was defined through micropalaeontological analysis (palynomorphs and foraminifera) where the major biotic extinctions occur. Palynomorphs characterize the end of the Cretaceous with extinctions of many species of Dinogymnium, Cricotriporites almadaensis and Ariadnaesporites sp., while the beginning of the Tertiary shows the appearance of many pollens/spores such as Echitriporites trianguliformis, Schizeoisporites eocenicus, Proxapertites cursus and palms. Foramin-

Fig. 3. (A) Hummocky cross-stratification which occurs in the uppermost beds of Gramame Formation (Ponta do Funil area). (B) Photomicrography of sample recovered from bed D, Poty Quarry (sample 25). Phosphatized bioclasts (such as large fragment of serpulid, $S$, with a phosphatized interior, planctonic, $P$, and benthonic, $B$, foraminera, fish bones, $F$ ) and intraclasts $(I)$ in micritic matrix. Crossed nicols; scale bar $=0.4 \mathrm{~mm}$. (C) Erosional nature $(E)$ of the lithologic contact (dashed linc), between Gramame $(G)$ and Maria Farinha Formations $(M)$, in the Ponta do Funil area. Note abundant phosphatized fragments $(F)$ and fining-upward grain-size distribution at the base of the Maria Farinha Formation. 
era characterize the end of the Cretaceous with the disappearance of species such as Rugoglobigerina ex gr. rugosa, Contusotruncana contusa, Pseudoguembelina costulata etc., while the beginning of the Tertiary shows the continuity of Guembelitria cretacea as well as the appearance of Eoglobigerina edita and Parvularugoglobigerina eugubina, among others (Fig. 4).

At the same level where a biotic crisis is recorded, the geochemical analysis shows relevant iridium (Ir) and total organic carbon (TOC) anomalies. An Iranomaly $(0.69 \mathrm{ppb})$ is identified in bed $\mathbf{I}$ (Fig. 4$)$, in conditions very similar to other sections around the world (Donovan et al., 1988; Bourgeois et al., 1988; Baadsgaard et al., 1988; Johnson et al., 1989; Schmitz, 1992; Albertão, 1993). The anomaly is almost 26 times greater than the mean value of the other samples collected in the studied arca. High Ir concentrations may be artificially induced by an increase of the clay content in the deposit. However, the ratios $\mathrm{Ir} / \mathrm{Fe}$, Ir/Al (geochemical data) and Ir/clay (clay content obtained by XRD) confirm the anomaly (Figs. 5A, 5B)

Bed I also records an anomalous value of TOC

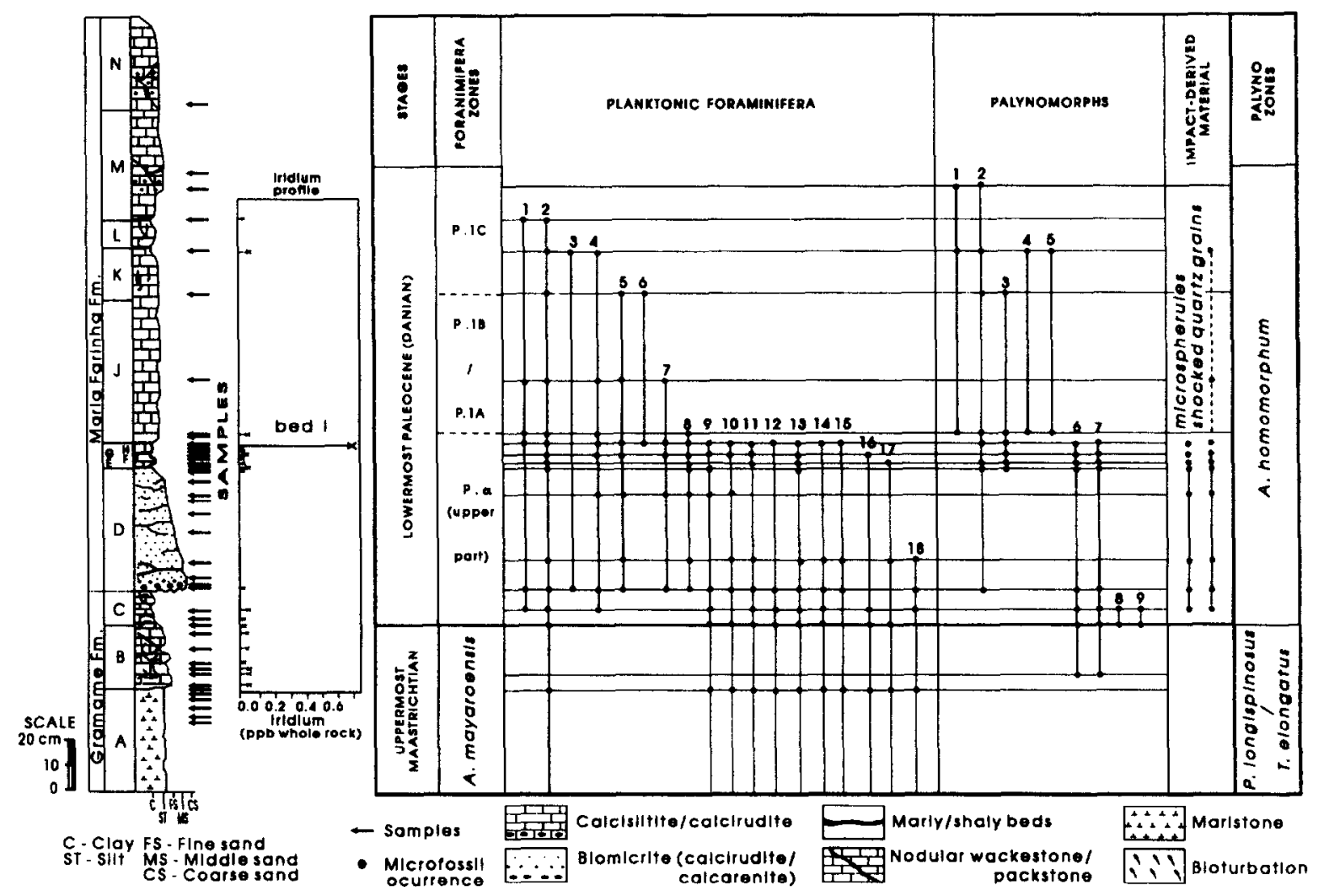

Fig. 4. Litho- and chemostratigraphy (iridium) and distribution of microfossils across the measured $\mathrm{K}-\mathrm{T}$ boundary section in the Poty Quarry. Note the iridium anomaly in a $2-3 \mathrm{~cm}$ thick claystone (hed I) in the lower Danian (planktonic foraminifera zone upper P. $\alpha$ ). Planktonic Foraminifera (analysis by Dr. Eduardo A. M. Koutsoukos): (1) Woodringina hornestownensis; (2) Guembelitria cretacea; (3) Parasubbotina pseudobulloides; (4) W. claytonensis; (5) P. aff. pseudobulloides; (6) Eoglobigerina eobulloides; (7) Praemurica taurica; (8) Parvularugoglobigerina eugubina; (9) Pseudotextularia nuttalli; (10) Pseudoguembelina costulata; (11) P. palpebra; (12) Rugoglobigerina ex gr. rugosa; (13) R. scotti; (14) Contusotruncana contusa; (15) R. reicheli; (16) Globotruncana aegyptiaca; (17) Racemiguembelina fructicosa; (18) Globotruncana falsocalcarata. Palynomorphs (analysis by Dra. Marilia S. P. Regali): (1) Proxapertites cursus; (2) Pterospermopsis sp.; (3) Veryhachium reductum; (4) Schizeoisporites eocenicus; (5) Echitriporites trianguliformis; (6) Ariadnaesporites sp.; (7) Dinogymnium spp.; (8) Cricotriporites almadaensis; (9) Crassitriapertites vanderhammeni. 

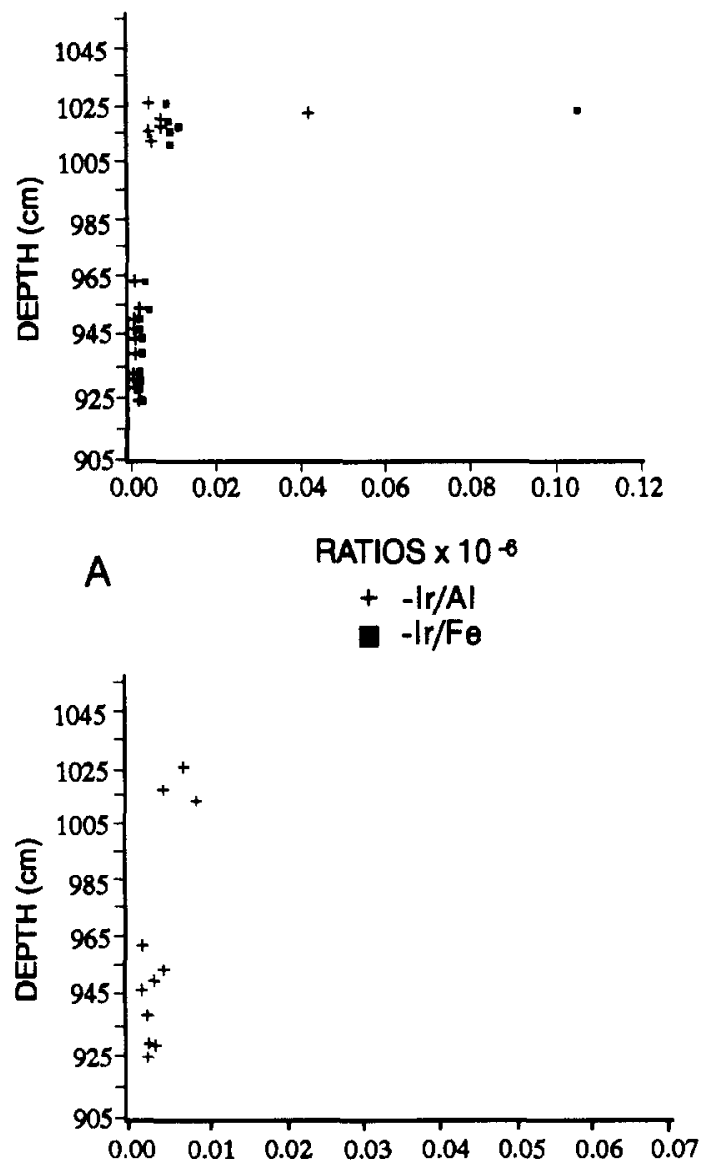

B (Ir / clay $) \times 10^{-7}$

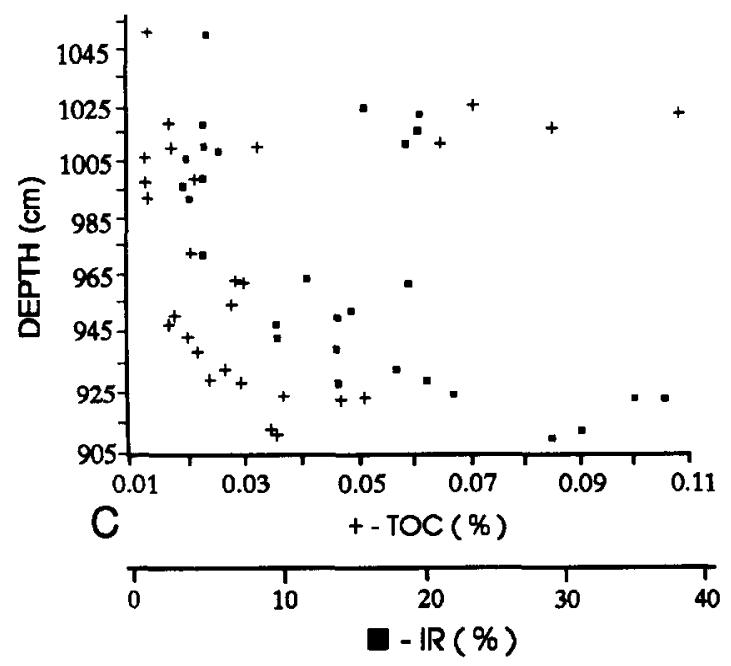

which may reflect high carbon concentration related to the presence of soot. The TOC anomaly is supported by its independence in relation to the insoluble residue content in the analyzed samples (Fig. 5 C).

Microtektite-like microspherulcs and shattercd fragments of shock-metamorphosed quartz grains are common to relatively frequent in the residues from beds near the $\mathrm{K}-\mathrm{T}$ boundary, and are very rare in the subsequent lower boundary beds (Koutsoukos, 1994). Nearly 100 microspherules were picked and are currently being studied for their morphological characteristics and geochemistry (Koutsoukos, in prep.). The microspherules range from 80 to $160 \mu \mathrm{m}$ in diameter and are spherical or teardrop in shape; their appearance is similar to that of known tektites and microtektites (Fig. 6A). The shattered shocked quartz grains are relatively rare and present microscopic planar features (Fig. 6B).

\section{Discussion on the $\mathrm{K}-\mathrm{T}$ boundary position}

The micropalaeontological evidence reveals a period of crisis at the $\mathrm{K}-\mathrm{T}$ boundary clay (bed $\mathrm{I}$; Fig. 4), with the extinction datum of nearly all the latest Maastrichtian planktonic foraminifera, and of many groups of dinoflagellates, pollens and spores (Albertão, 1993). The coeval stratigraphic record of the TOC and iridium anomalies, common shattered fragments of shock-metamorphosed quartz grains and microtektite-like microspherules, with the mass biotic extinction datum, in bed I, give strength to the definition of the $\mathrm{K}-\mathrm{T}$ boundary in the Poty Quarry section. Furthermore, it provides direct evidence that supports an extraterrestrial bolide-impact origin for the terminal Cretaceous event and the related boundary beds.

Fig. 5. Ir/AI and $\mathrm{Ir} / \mathrm{Fe}$ ratios (A) and $\mathrm{Ir} /$ clay ratio (B), which confirm the iridium anomaly in layer 1 (interval of 1021-1023 $\mathrm{cm}$ ). (C) The total organic carbon (TOC) anomaly in layer I and its independence from the insoluble residue (IR) content. Base of Maria Farinha Formation, lowermost Paleocene, Poty Quarry; 0 $\mathrm{cm}$ is the datum at the base of the quarry ('reference level' in Fig. 2) and 'depth' means thickness of the section above the datum. 
Nevertheless, Koutsoukos (1994) and Albertão et al. (1994) observed the first occurrence of Danian taxa of planktonic foraminifera and even of microspherules and shocked quartz in bed C (Fig. 4). For this reason, the $\mathrm{K}-\mathrm{T}$ boundary is here considered between beds $B$ and $\mathbf{C}$ instead of bed $\mathbf{I}$.

At just one portion of the Poty Quarry very rare burrows were observed in bed D (burrows which were probably formed after the event responsible for the deposition of bed D). One could take into account the possibility that bioturbation across these beds may have mixed microfossils of different ages. This possibility will be investigated in a future field work because there was no apparent sign of bioturbation in the parts which were sampled.

\section{Bed D}

Bed D, a 50-cm-thick bioclastic/intraclastic packstone (Fig. 3B), resembles the 'graded skeletal sheet' facies of Aigner (1985), although the coarse texture prevents the preservation of fine sedimentary structures. Bed D marks the lowermost boundary of the Maria Farinha Formation, which shows unique stratigraphic and sedimentological characteristics indicating rapid deposition: (i) a sharp erosive base (Fig. 3C), followed by (ii) a fining-upward succession composed of shells, siliciclasts and abundant phosphatized fragments at the base (Figs. $3 \mathrm{C}$ and 7A), (iii) extensive mixing and fragmentation of fossils derived from different palaeodepths and reworked from older strata (Figs. 3B and 7B), (iv) coarse grain-size (intraclasts and bioclasts of up to 9 $\mathrm{cm}$ in diameter were found) and poor sorting (Fig. 7B), (v) scattered impact-derived products (microtektite-like microspherules and shock-metamorphosed quartz grains; Figs. 6A and 6B), (vi) interference ripples at the top of the bed (Fig. 7C), and (vii) great lateral continuity in the basin (for at least 30 $\mathrm{km}$ in Pernambuco). The great lateral continuity of bed $\mathbf{D}$ is one of its most conspicuous characteristics because it is possible to follow this bed from the Poty Quarry to the Ponta do Funil area (Fig. 1). Between these areas, in the Itamaraca island, a core was recovered from well 2-Ist-1-PE, drilled by PETROBRÁS. This core also exhibits the presence of bed $D$.
Bed $\mathbf{D}$ is overlain by alternating beds of finegrained limestones (beds $\mathbf{F}$ and $\mathbf{H}$ ) and marlstones (beds E, G and I; see Fig. 4) which indicate a progressive reduction of the depositional energy. Impact-derived material (abundant shock-metamorphosed quartz grains, with several sets of intersecting deformation lamellae, and microtektite-like microspherules) also occur in beds C to I (Fig. 4) but have not been found below bed $\mathbf{C}$. In addition, bed I exhibits Ir and TOC anomalies.

\section{Semi-quantitative modelling}

The sedimentary records given above, such as the mixture of fossils (derived from different environments-deeper and shallower, and also reworked from older strata) and the presence of coarse siliciclastic grains indicate that a high-energy mechanism played a role in the deposition of bed $\mathbf{D}$.

Bourgeois et al. (1988) suggest that coarse-grained sedimentary deposits at or close to the $\mathrm{K}-\mathrm{T}$ boundary may be related to a huge tsunami wave generated by a meteorite impact. The occurrence of tsunami beds or deposits related to convulsive geological events have been reported recently from sections in Braggs and Brazos River (Bourgeois et al., 1988), Haiti (Florentin et al., 1991), Mexico (Smit et al., 1992), Cuba (Iturralde-Vinent, 1992), and in DSDP (Deep Sea Drilling Project) sites (Alvarez et al., 1992).

A semi-quantitative modelling on the hypothesis of the depositional processes active during that boundary event indicates that, most likely, a major tsunami wave formed bed $D$. The methods described by Bourgeois et al. (1988) and the mechanism indicated by Duringer (1985; see Fig. 8) were applied for the calculation of such a process. The dimension of the giant wave which was responsible for the deposition of bed $D$ was estimated, assuming for the Pernambuco $\mathrm{K}-\mathrm{T}$ boundary succession the same conditions as considered for the Brazos River.

The following observations were also taken into account (Table 1):

(1) The micropalaeontological data based on foraminera suggest that the deposition of bed $\mathbf{D}$ took place in a relatively deep neritic environment, that is, at a water depth between 100 and $200 \mathrm{~m}$ (interpreta- 


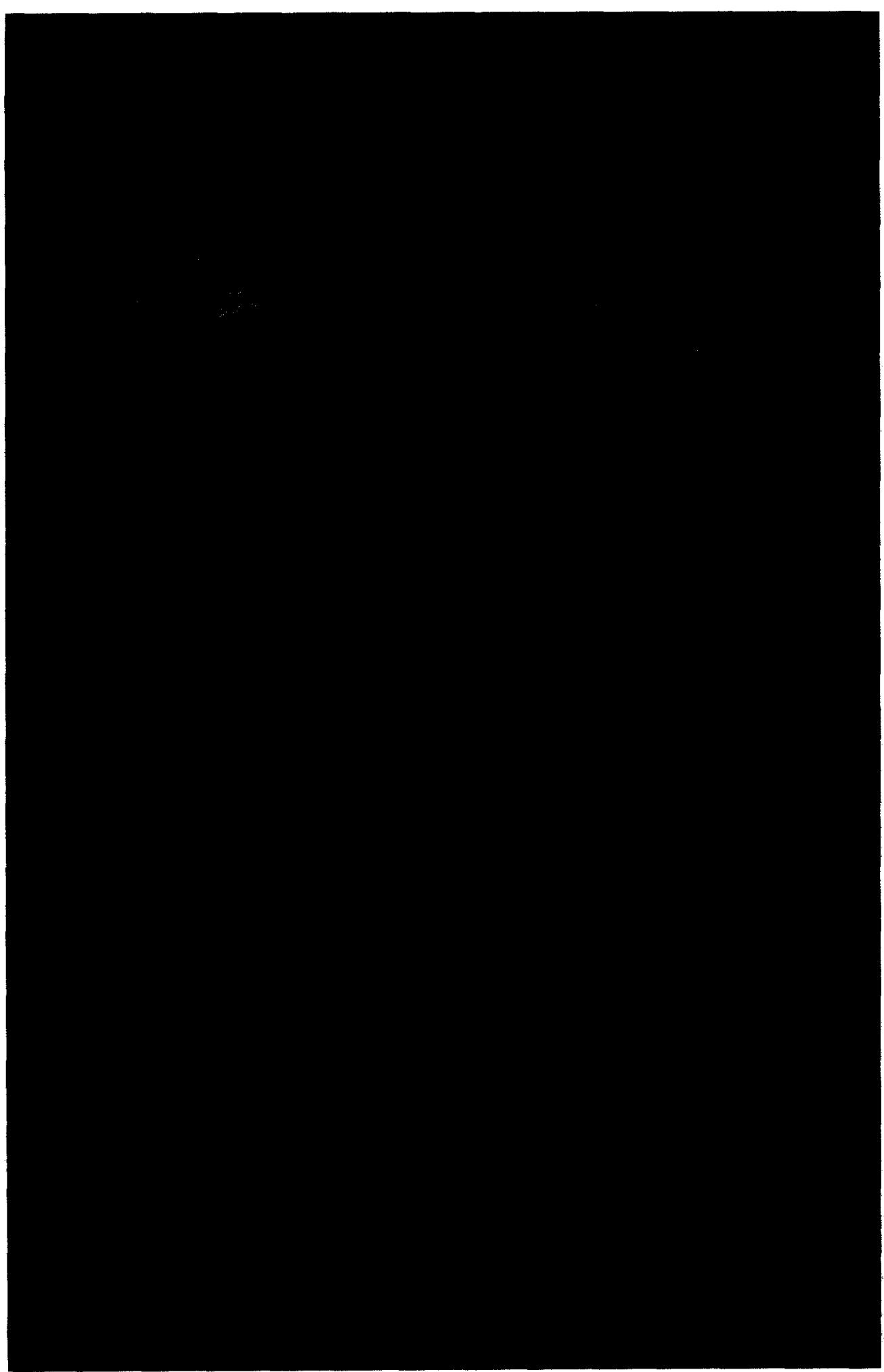


Table 1

Semi-quantitative modelling based on the characteristics of bed $\mathbf{D}$

\begin{tabular}{|c|c|c|}
\hline $\begin{array}{c}\text { ESTIMATED PALEODEPTH (I) } \\
50-200 \mathrm{~m}(100 \mathrm{~m})\end{array}$ & $\begin{array}{c}\text { LARGEST CLASTS ( II) } \\
2-9(5 \mathrm{~cm})\end{array}$ & $\begin{array}{c}\text { WAVE-LENGTHS (ABOVE LAYER D) } \\
\text { (III) } \\
15-20 \mathrm{~cm}(15 \mathrm{~cm})\end{array}$ \\
\hline $\begin{array}{c}1+\mathrm{II} \Rightarrow \mathrm{U}^{*} \text { REQUIRED } \\
15 \mathrm{~cm} / \mathrm{s}\end{array}$ & $\mathrm{I}+\mathrm{II}+\mathrm{U}^{*} \begin{array}{c}\Rightarrow \text { WAVE HEIGHT/VELOCITY/LENGTH } \\
>20 \mathrm{~m} / 112 \mathrm{~km} / \mathrm{h} / 112 \mathrm{~km}\end{array}$ & $\begin{array}{c}\text { III } \Rightarrow \text { REDUCIION OF U* } \\
15 \mathrm{~cm} / \mathrm{s} \Rightarrow \mathrm{I} \mathrm{cm} / \mathrm{s}\end{array}$ \\
\hline
\end{tabular}

Table 2

Estimation of shear velocities vs. wave heights (Bourgeois et al., 1988):

\begin{tabular}{|c|c|c|c|c|c|c|c|}
\hline \multirow[t]{2}{*}{$T(\min )$} & \multicolumn{7}{|c|}{ Shear velocity $(\mathrm{cm} / \mathrm{s})$ for wave heights of } \\
\hline & $2 \mathrm{~m}$ & $4 \mathrm{~m}$ & $6 \mathrm{~m}$ & $8 \mathrm{~m}$ & $10 \mathrm{~m}$ & $15 \mathrm{~m}$ & $20 \mathrm{~m}$ \\
\hline \multicolumn{8}{|c|}{ Water depth $=50 \mathrm{~m}$} \\
\hline 8 & - & 1.4 & 1.9 & 2.4 & + & + & + \\
\hline 12 & 2.1 & 3.8 & 5.4 & 7.0 & 8.5 & 12.1 & + \\
\hline 16 & 2.7 & 4.9 & 6.9 & 8.9 & $10.9^{*}$ & (15.5) & $(20.0)$ \\
\hline 20 & 2.9 & 5.3 & 7.6 & 9.8 & $(11.9)$ & $(17.0)$ & $(21.9)$ \\
\hline \multicolumn{8}{|c|}{ Water depth $=100 \mathrm{~m}$} \\
\hline 8 & - & - & - & - & - & + & + \\
\hline 12 & - & 1.2 & 1.7 & 2.3 & 2.7 & 3.3 & 4.9 \\
\hline 16 & 1.4 & 2.5 & 3.5 & 4.5 & $5.5^{*}$ & (7.9) & $(10.1)$ \\
\hline 20 & 1.8 & 3.2 & 4.5 & 5.9 & $(7.2)$ & $(10.2)$ & (13.1) \\
\hline
\end{tabular}

$-=$ subcritical (no transport).

$+=$ wave too steep, will collapse.

* = maximum recorded wave.

Parentheses indicate extreme wave conditions.

tion based on autochthonous benthic foraminifera recovered from hemipelagic clay bed I; Albertão, 1993).

(2) The biggest clasts in bed $\mathbf{D}$ have diamcters from 2 to $9 \mathrm{~cm}$. The value of $5 \mathrm{~cm}$ was used in the calculations, which is the same value used by Bourgeois et al. (1988).

(3) The wavy bedding structures of beds $\mathbf{E}, \mathbf{F}, \mathbf{G}$ and $\mathbf{H}$ (Fig. 7C) indicate wave-lengths which range from 15 to $20 \mathrm{~cm}$. It was used again the same value of Bourgeois et al. (1988): $15 \mathrm{~cm}$.

(4) The exclusive action of eustatic sea-level fluctuations would not be enough to create structures such as fining-upward and wavy bedding.

(5) Turbidity currents would produce strongly asymmetrical ondulations (e.g. current ripples).

(6) Even the strongest storm would not have been able to generate waves to move the large clasts

Fig. 6. (A) Scanning electron photomicrographs of two selected microtektite-like microspherules recovered from layer I in the Poty Quarry. Scale bar $=20 \mu \mathrm{m}$. The microspherules have surfaces with protruding mounds or protrusions $(p)$ of various shapes and sizes, flow-ridge patterns and 'crater-like' pits ( $c$, circular to irregularly shaped). (B) Photomicrography of a shock-metamorphosed quartz grain from bed D (sample from Poty core \#1, depth $478.5-480.0 \mathrm{~cm}$ ) exhibiting multiple intersecting sets of sharp and straight planar lamellae. Scale bar $=150 \mu \mathrm{m}$. 

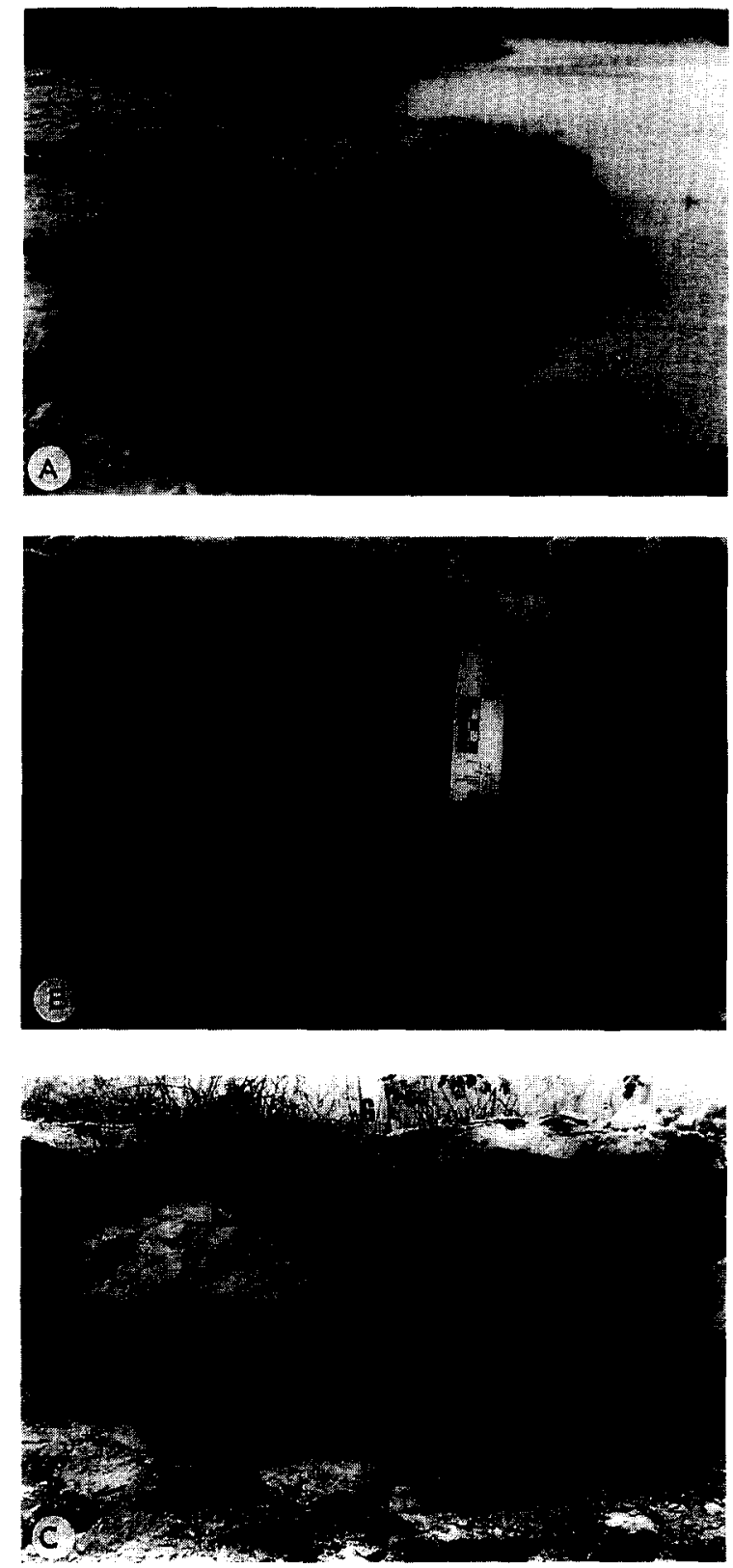

Fig. 7. (A) Detail of bed D presenting fining-upward grain-size distribution. The top of the sequence is bed $\mathbf{H}$, which marks the limit between the first two levels of the Poty Quarry. (B) Block of bed D (Poty Quarry) with its characteristic heterogeneous composition (phosphatized fragments $P$, fragments of gastropods $G$ and pelecypods $P L$, siliciclasts $S$, intraclasts $I$ ) and coarse grain size. (C) Detail of bed $\mathbf{D}$, Poty Quarry, with wavy bedding structure in beds $\mathbf{E}, \mathbf{F}$ and $\mathbf{G}$. which occur in bed $\mathbf{D}$, deposited at palaeodepths of 100 to $200 \mathrm{~m}$. Besides that, hummocky cross-stratification was not observed in the outcrops of bed $D$. This structure occurs below bed $\mathbf{D}$ in the Ponta do Funil area.

$\Lambda$ ccording to Bourgeois et al. (1988) shear velocities $\left(U^{*}\right)$ of at least $15 \mathrm{~cm} / \mathrm{s}$ would be needed to erode and transport clasts of about $5 \mathrm{~cm}$ in diameter; $U^{*}$ of $15 \mathrm{~cm} / \mathrm{s}$ at water depths of more than $100 \mathrm{~m}$ requires waves higher than $20 \mathrm{~m}$ (Table 2). Based on the wave height it is also possible to estimate its velocity $(C=112 \mathrm{~km} / \mathrm{h})$ and length $(L=112 \mathrm{~km})$; such waves are associated with major tsunami processes.

Furthermore, the wave-lengths of sedimentary structures in beds $\mathbf{E}, \mathbf{F}, \mathbf{G}$ and $\mathbf{H}(15$ to $20 \mathrm{~cm})$ indicate $U^{*}$ of only $1 \mathrm{~cm} / \mathrm{s}$ (using the same principles as Bourgeois et al., 1988). Therefore, a reduction of $U^{*}$ from at least $15 \mathrm{~cm} / \mathrm{s}$ (at the base of bed D) to $1 \mathrm{~cm} / \mathrm{s}$ (beds which overlie bed $\mathrm{D}$ ) is required. Such a reduction of shear velocities is commonly attributed to tsunami processes in platform settings. Beds $\mathbf{E}, \mathbf{F}, \mathbf{G}$ and $\mathbf{H}$ present wave bedding out-ofphase, which also corroborates the reduction of velocity toward the top of bed D (Table 1). These fine-grained graded beds could have been deposited by multiple attenuated waves or through wave reflection, known from shelf settings (Duringer, 1984; Bourgeois et al., 1988). Probable impact-derived material, such as iridium, microtektite-like microspherules and shattered shock-metamorphosed quartz grains are concentrated in the more slowly deposited hemipelagic bed $\mathbf{I}$. Bed $\mathbf{H}$ and particularly bed $\mathbf{I}$ are bioturbated, which indicates some break in sediment accumulation.

\section{Conclusions}

The Poty Quarry outcrops represent, as compared to other areas surveyed in the Brazilian marginal basins, the most complete shallow-marine sedimentary succession of the K-T boundary. There is evidence of a terminal Cretaceous event (probably meteorite impact): biotic extinctions, anomalies of iridium detected for the first time in low latitudes of the Southern Hemisphere (particularly in South Amer- 
ica) and of TOC, impact-derived exotic products (such as microtektite-like microspherules and shock-metamorphosed quartz grains), and a possible impact-generated tsunamite.

If the $\mathrm{K}-\mathrm{T}$ boundary really occurs in between beds $\mathbf{B}$ and $\mathbf{C}$, the tsunami beds may be related to an early Danian bolide impact in the northern South Atlantic area. All that seems to be similar to the apparently coeval tsunami beds in Texas (Mont- gomery et al., 1992), and in the Caribbean areas (Florentin et al., 1991). In these regions the geologic record at the $\mathrm{K}-\mathrm{T}$ boundary was strongly disturbed.

However, if stratification was affected by bioturbation and the $\mathrm{K}-\mathrm{T}$ boundary is represented by bed I, two hypotheses may be taken into account, considering the conspicuous lateral continuity of bed $\mathbf{D}$ and an oceanic gateway between the early Gulf of Mexico and the northern portion of the South Atlantic
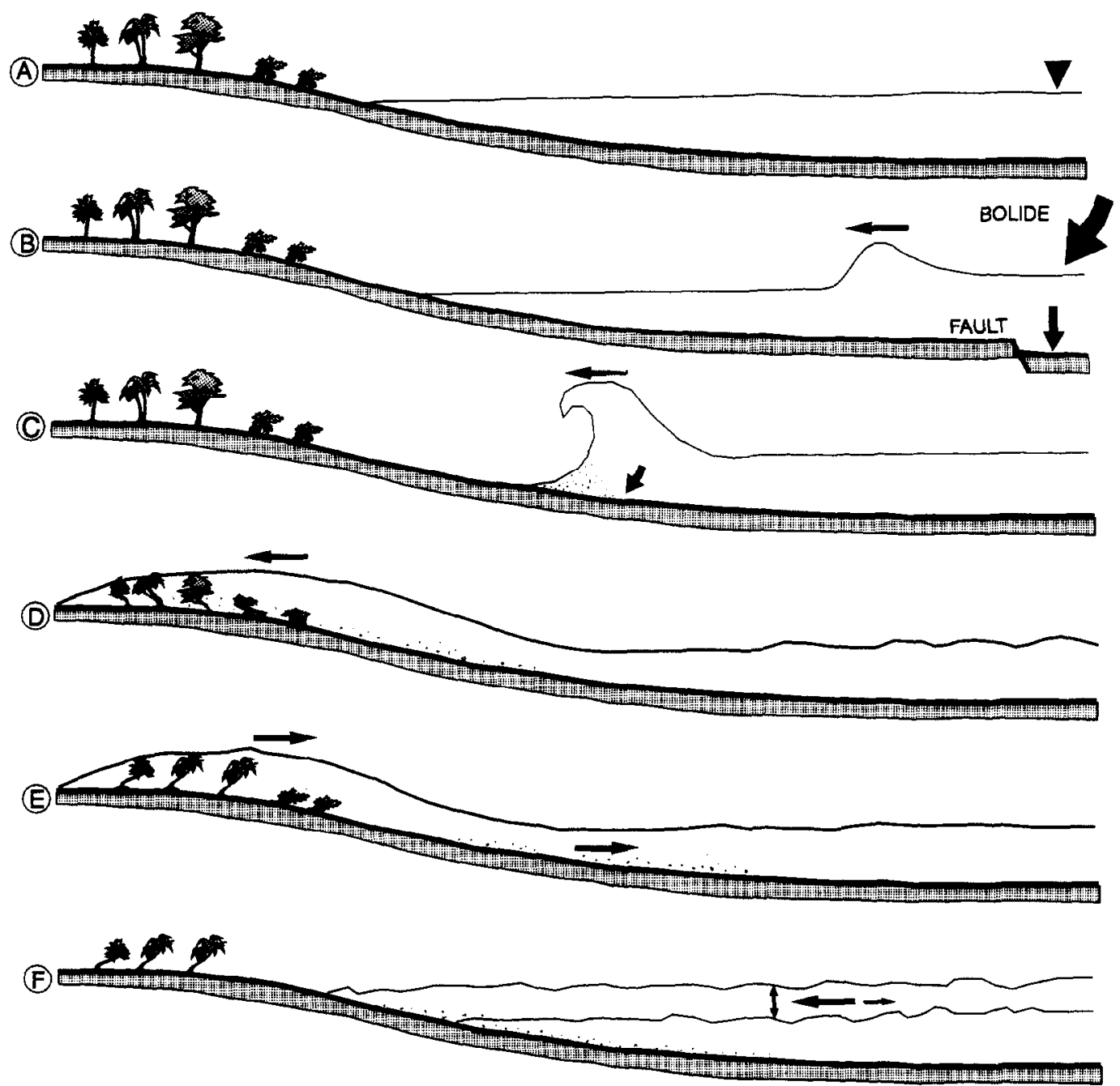

Fig. 8. Schematic representation of a tsunami (adapted from Duringer, 1984): (A) pre-event stage; (B) early stage (caused by e.g. a bolide impact or a submarine fault) generating a wave of small amplitude $(2-3 \mathrm{~m})$, great length $(200 \mathrm{~km})$ and high velocity $(800 \mathrm{~km} / \mathrm{h}) ;(\mathrm{C})$ amplitude increases $(10-30 \mathrm{~m})$ and wave velocity decreases $(60 \mathrm{~km} / \mathrm{h})$ as a result of friction on the sea floor; (D) coastal flooding; (E) backflow (commonly responsible for the deposition of a tsunami bed); $(F)$ subsequent oscillations of high frequency and small amplitude. 
(Koutsoukos, 1992): (i) a close coeval and genetic relationship between Yucatán impact at the $\mathrm{K}-\mathrm{T}$ boundary (the Chicxulub Crater; Hildebrand, 1991) and the impact-generated tsunami deposits found in Texas, the Caribbean, and bed $\mathbf{D}$ in Pernambuco, and (ii) the relationship of bed $\mathbf{D}$ with other probable impact(s) which may have happened somewhere in the South Atlantic, simultaneously with that of the Yucatán Peninsula.

\section{Acknowledgements}

The authors wish to thank Dr. Jorge C. Della Favera (State University of Rio de Janeiro) and the institutions PETROBRÁS, Universidade Federal de Ouro Preto, Los Alamos National Laboratory, Cia. de Cimento Votorantim (Pedreira Poty), and Universidade Federal de Pernambuco for their support in this research; Dr. Eduardo A. M. Koutsoukos (PETROBRÁs) for discussions, foraminera analysis and photographs which are included in Fig. 6, and Dra. Marilia S.P. Regali (PETROBRÁS) for the palynomorphs analysis; and also Drs. T. Shiki, G. Einsele and C.H.L. Bruhn for various suggestions.

\section{References}

Aigner, T., 1985. Storm Depositional Systems: Dynamic Stratigraphy in Modern and Ancient Shallow Marine Sequences. Lecture Notes in Earth Sciences, 3. Springer-Verlag, Berlin, 174 pp.

Albertão, G.A., 1993. Abordagem interdisciplinar e epistemológica sobre as evidências do limite Cretáceo-Terciário, com base em leituras efetuadas no registro sedimentar das Bacias da Costa Leste Rrasileira. M.Sc. Thesis, Federal University of Ouro Preto, 2 volumes, $251 \mathrm{pp}$.

Albertão, G.A. and Martins, P.P., Jr., 1992. O limite CretáceoTerciário nas Bacias Sedimentares da Costa Leste Brasileira. 35th Congr. Geol. Brazil, pp. 463-465 (abstr.).

Albertão, G.A., Koutsoukos, E.A.M., Regali, M.S.P., Attrep, M., Jr. and Martins, P.P., Jr., 1993. The Cretaceous-Tertiary boundary record in Eastem Marginal Sedimentary Basins of Brazil. Acta Geol. Leopoldensia, XVI: 5971.

Albertão, G.A., Koutsoukos, E.A.M., Regali, M.S.P., Attrep, M., Jr. and Martins, P.P., Jr., 1994. The Cretaceous-Tertiary boundary in Southem low-latitude regions: preliminary study in Pemambuco, Northeastem Brazil. Terra Nova, 6: 366-375.

Alvarez, L.W., Alvarez. W., Asaro, F. and Michel, H.V., 1980. Extraterrestrial cause for the Cretaceous-Tertiary extinction. Science, 208: 1095-1108.
Alvarez, W., Smit, J., Lowrie, W., Asaro, F., Margolis, S.V., Claeys, P., Kastner, M. and Hildcbrand, A.R., 1992. Proximal impact deposits at the $\mathrm{K}-\mathrm{T}$ boundary in the Gulf of Mexico: a restudy of DSDP leg 77 sites 536 and 540. Geology, 20: $697-700$.

Baadsgaard, H., Lerbekmo, J.F. and MacDougall, 1., 1988. A radiometric age for the Cretaceous-Tertiary boundary based upon $\mathrm{K}-\mathrm{Ar}, \mathrm{Rb}-\mathrm{Sr}$, and $\mathrm{U}-\mathrm{Pb}$ ages of bentonites from $\mathrm{Al}-$ berta, Saskatchewan, and Montana. Can. J. Earth Sci., 25: $1088-1097$.

Beurlen, K., 1967a. Estratigrafia da faixa sedimentar costeira Recife-João Pessoa. Bol. SBG, 16: 43-53.

Beurlen, K., 1967b. Paleontologia da faixa costeira Recife-João Pessoa. Bol. SBG, 16: 73-79.

Bourgeois, J., Hansen, T.A., Wiberg, P.L. and Kauffman, E.G., 1988. A tsunami deposit at the Cretaceous-Tertiary boundary in Texas. Science, 241: 567-570.

Chang, H.K., Kowsmann, R.O. and Figueiredo, A.M.F., 1988. New concepts on the development of East Brazilian Marginal Basins. Episodes, 11: 194-202.

Donovan, A.D., Baum, G.R., Blechschmidt, G.L., Loutit, T.S., Pflum, C.E. and Vail, P.R., 1988. Sequence stratigraphic setting of the Cretaceous-Tertiary boundary in Central Alabama. In: C.K. Wilgus, H. Posamentier, B.S. Hastings, J. Van Wagoner, C.A. Ross and C.G.St.C. Kendall (Editors), Sea-Level Changes: An Integrated Approach. SEPM, Spec. Publ., 42: 299-307.

Duringer, P., 1984. Tempêtes et tsunamis: des dépôts de vagues de haute énergie intermittente dans le Muschelkalk supérieur (Trias germanique) de l'Est de la France. Bull. Soc. Géol. Fr., XXVI: $1177-1185$.

Florentin, J.-M., Maurrasse, R. and Sen, G., 1991. Impacts, tsunamis, and the Haitian Cretaceous-Tertiary boundary bed. Science, 252: 1690-1693.

Hildebrand, A.R., Penfield, G.T., Kring, D.A., Pilkington, M., Camargo, A., Jacobson, S.B. and Boynton, W.V., 1991. Chicxulub crater: a possible Cretaceous/Tertiary boundary impact crater on the Yucatán Peninsula, Mexico. Gcology, 19: 867-871.

Iturralde-Vinent, M.A., 1992. A short note on the Cuban late Maastrichtian megaturbidite (an impact-derived deposit?). Earth Planet. Sci. Lett., 109: 225-228.

Johnson, K.R., Nichols, D.J., Attrep, M. and Orth, C.J., Jr., 1989 High-resolution leaf-fossil record spanning the Cretaceous/ Tertiary boundary. Nature, 340: 708-710.

Koutsoukos, E.A.M., 1992. Late Aptian to Maastrichtian foraminiferal biogeography and palaeoceanography of the Sergipe Basin, Brazil. Palaeogeogr., Palaeoclimatol., Palaeoecol., 92: 295-324.

Koutsoukos, E.A.M., 1994. The Cretaceous-Tertiary boundary in Pernambuco, Northeastern Brazil. 2nd Colloquium of Stratigraphy and Paleogeography of the South Atlantic, Angers, pp. 81-82 (abstr.).

Mabesoone, J.M., 1967. Sedimentologia da faixa costeira RecifeJoão Pessoa. Bol. SBG, 16: 57-72.

Mabesoone. J.M., Tinoco, I.M. and Coutinho, P.N., 1968. The Mesozoic-Tertiary boundary in northeastern Brazil. Palaeogeogr., Palaeoclimatol., Palaeoecol., 4: 161-185. 
Montgomery, H., Pesagno, E., Soegaard, K., Smith, C., Muños, I. and Pessagno, J., 1992. Misconceptions concerning the Cretaceous/Tertiary boundary at the Brazos River, Falls County, Texas, Earth Planet. Sci. Lett., 109: 593-600.

Schmitz, B., 1992. Calcophile elements and Ir in continental Cretaceous-Tertiary boundary clays from the western interior of the USA. Geochim. Cosmochim. Acta, 56: 1695-1703.

Smit, J., 1990. Meteorite impact, extinctions and the CretaceousTertiary boundary. Geol. Mijnbouw, 69: 187-204.

Smit, J., Montanari, A., Swinbume, N.H.M., Alvarez, W., Hildebrand, A.R., Margolis, S.V., Claeys, P., Lowrie, W. and Asaro, F., 1992. Tektite-bearing, deep-water clastic unit at the Cretaceous-Tertiary boundary in northeastem Mexico. Geology, 20: 99-103.
Stinnesbeck, W., 1989. Fauna y microflora en el limite Cretacico-Terciario en el Estado de Pernambuco, Noreste de Brasil. Contribuciones de los Simposios sobre Cretácico de America Latina, Parte A: Eventos y Registro Sedimentario, pp. 215-230.

Tinoco, I.M., 1967. Micropaleontologia da faixa sedimentar costeira Recife-João Pessoa. Bol. SBG, 16: 81-85.

Tinoco, I.M., 1971. Foraminíferos e a passagem entre o Cretáceo e o Terciário em Pernambuco. Ph.D. Thesis. University of São Paulo, São Paulo, 132 pp. (unpubl.).

Tinoco, I.M., 1976. Foraminíferos planctônicos e a passagem entre o Cretáceo e o Terciário, em Pernambuco, Nordeste do Brasil. 29th Congr. Geol. Brazil, Anais, SBG, 2: 17-35. 